\title{
H3C12 Gene
}

National Cancer Institute

\section{Source}

National Cancer Institute. H3C12 Gene. NCI Thesaurus. Code C154546.

This gene plays a role in chromatin structure. 